\section{Musings from Office Practice}

Childhood is a short season but may be considered one of the most beautiful ones. As a pediatrician one has the pleasure and privilege to help children navigate it. Each child we encounter is a divine appointment; these little ones touch your heart and embrace your mind giving you a lighter view of life. As I grow older, I look back at the lessons I learnt from some of my most memorable encounters in practice.

Shakespeare said 'What's in a name?' To learn more, read on. As a young child entered my cabin, I called him by the name on the file. The father replied that this was his birth name. On being asked the child said his name was 'Lucky'. The mother explained that this was his pet name. So I asked the child for his name again. Now his answer was 'Bahubali'. Both parents laughed and said this was his self proclaimed name. I prodded the child to tell me the name that was used in school and he replied 'Scholar'. His parents added that all his school mates called him by this name. I patiently waited for his real name and finally was rewarded with a loud 'Hrishi' that was spelled out for me in the next breath so that I would write it correctly. I learnt that day the venerable bard could be wrong on occasion.

Children are spontaneous in nature. They have wonderful outbursts that just come out unplanned, unbridled and full of surprises. As a child walked into my office, I extended my hand and said 'Hello'. In response, he immediately placed his hands next to his ears and loudly said 'Hello' mimicking the action of talking on a cell phone. On enquiring 'How is school?' he replied 'Today is a holiday'. When I protested that it wasn't a holiday for me, pat came the response 'You should start going to school'. It made me realize that spontaneity is a skill mastered in childhood and lost with age!

Children love to show whenever they get a chance. Time and again my little patients seek my attention to their new wrist watches which come in vibrant colors, shapes and sizes. I express appreciation as the child enthusiastically displays its color, flashing lights and several audible tunes. When asked whether the school allows watches, they say no but state that it should be, to tell the time. When I ask them the time, they stare at the watch, look around and ask the parent to tell me the time. Innocence thy name is childhood!

Children are inquisitive by nature. They pose questions at the drop of a hat. For everything they see or do, there is a 'what', 'when', 'where', 'how', 'who' or 'why' question sure to follow. I recollect one mother who became distressed with the growing number of questions and sought my professional help. Being religious the family regularly visited temples. The little one insisted on being shown the real God and not the one in pictures, pedestals or temples. Understandably I was not competent enough to satisfy his theological curiosity. I learnt 'fertile minds never ever stop questioning'.

Children are fond of games, and to get the child talking I always ask him or her about their favorite ones. Recently, a smart one eagerly started enumerating the name of the games he played - Turbo fast, Masha and the beast, Poptropica etc. Looking at my puzzled face, the mother intervened to say that these were his favorite mobile games. That is when I realized that mobiles are the new playgrounds and playmates for kids in the $21^{\text {st }}$ century.

An obstinate child is a source of headaches and heartaches for parents. A parent once told me that he was being blackmailed. When I wondered whether he had come to the right place, he clarified that the blackmailer was his son. The child refused to do anything unless he got a toy, car, chocolate or his demands were met beforehand. The father was fed up with this behavior and pleaded me to find a way to stop this harassment from the child. I referred him to a book on parenting and a counselor. Many children instruct their parents not to divulge their bad habits (love for junk food and excessive TV watching) to me. When the parents narrate these with the hope that I shall instill some wisdom in child's head, they look angrily at their parents for exposing them, pout, and refuse to interact after becoming "katti" with both - parents and me. The parents look at me in anticipation, whereas I do not know whether to smile or pretend to scold the child.

While we attempt to teach our children all about life, our children end up teaching us what life is all about. The world indeed appears very beautiful if we learn to look it through a child's eyes. Let us all try to rediscover the 'child' within us.

Funding: None; Competing Interest: Inspired by children who have a special way to adding joy every day.

RHISHIKESH P THAKRE Neo Clinic and Hospital, 27, Samarth Nagar, Aurangabad, Mahsarashtra. rhishikeshthakre@hotmail.com 